\title{
Econometric Analysis of Factors Affecting Farmers' Adoption of Water Saving Technologies: A Case Study of Raised-bed Technology in Egypt
}

\author{
Eman AbdAllah \\ Researcher, Economic Analysis of Agricultural Commodities Department; Agricultural \\ Economics Research Institute; Agricultural Research Center; Egypt \\ Atef Swelam Bezaiet Dessalegn Boubaker Dhehibi \\ International Center for Agricultural Research in the Dry Areas (ICARDA) - Agricultural \\ Engineering Department, Faculty of agriculture, University of Zagazig, Egypt
}

\section{Abstract}

This paper aims to present results of a socio-economic investigation into factors affecting the adoption of mechanized raised bed (MRB) technology in wheat production in Sharkia Governorate of Egypt. The sample consists of 70 wheat farming households, of which 50\% had adopted the technology. One dependent and fourteen explanatory variables were selected. The dependent variable is a binary variable (either adoption or no adoption), while explanatory variables include age, education, family size, farming experience, number of work days spent by labor force, land ownership, practicing of off-farm activities, income level, access to credit, membership in community-based organizations, role of livestock, contact with extension officers, as well as knowledge of the technology and attitude towards it. Data were collected during the 2013-2014 growing season. The Binary Logistic Regression Model was applied and the data was analyzed using SPSS statistical package. Six of the selected variables were found to be highly to fairly significant in explaining wheat farmer's response to adoption of raised bed farming; these are knowledge of the technology, age, farming experience, education family size and land ownership. The test yielded a Chi-square of 6.615, with a p-value (significance) of 0.579, indicating a good fit for the estimated binary logistic regression model. Results provide important guidelines for policy formulation and decision making in regards to technology adoption drivers.

Keywords: Raised Bed, Socio-Economic Modeling, Farmer Adoption, Water Saving

\section{Introduction}

Raised beds are structures formed by mounding up loose soil, usually from a tilled, flat surface, in a way that they regularly alternate with furrows. Beds can vary in width $(0.25-2.00 \mathrm{~m})$ and the number of crop rows on each bed (single rows for crops like cotton, maize, sugarcane; and multiple rows per bed for cereals). Often the bed width is determined by the width of machinery used, either the tractor axle width corresponding to furrow to furrow width, or multiples thereof (Roth et al 2005).

Raised bed (RB) farming is not a new idea. In many parts of the world soil beds have been raised and furrows used for irrigation for centuries. Around the world, the technique has been used for many years by home gardeners and commercial vegetable and flower growers to assist with drainage.

The systematic optimization of the technology started during the 1970's. Early initiatives appeared in the south of North America (southern United States and 
Econometric Analvsis of Factors Affecting Farmers' Adoption of Water । $\odot \mathrm{V} r$

Saving Technologies: A Case Study of Raised-bed Technology in Egypt

northern Mexico), where the technique of planting on narrow raised beds with irrigation water confined to furrows between the beds, was field tested. By 2005, more than $95 \%$ of the farmers in the Yaqui Valley in northwestern Mexico had changed from the previous practice of planting most crops (especially wheat) on the flat with flood/basin irrigation to the establishment of all their crops (including wheat) on tilled freshly raised beds using furrow irrigation. These crops were planted in rows on top of the beds, which normally measure 70-100 cm wide between bed centers. In Australia, in the early 1980s scientists from Tatura in Victoria developed a system of growing grain crops on raised beds and used furrows for irrigation (Tisdall and Adem, 1988). The system has been widely adopted for grain and horticultural crop production in the New South Wales Riverina districts, particularly around Griffith (Beecher et al 2005).

These early initiatives have resulted in the extension of bed planting technologies to many other areas with similar cropping systems, including irrigated areas in northwestern India, Pakistan, the eastern Gangetic Plains, the Yellow River Basin in China, central and western Asia, the Caucasus, North Africa and South America.

Despite the fact that wheat bread is the staple food for Egyptian consumers, Egypt still imports around $43 \%$ of the population's wheat consumption needs. Therefore, raising self-sufficiency in this strategic crop is a priority goal that Egypt's Agricultural Development Strategy seeks to achieve through increasing wheat production in main production governorates. To achieve that, it is important to answer the following questions: are there feasible, appropriate, reasonable technologies that can help raise self-sufficiency in wheat using the currently available old land area and irrigation water, which are both limited and thus represent the main challenges to achieving such strategic goal? And if the answer is yes, then, what are the factors affecting farmers' decision to adopt them? The Water and Livelihoods Initiative (WLI) of ICARDA implemented a project in Sharkia Governorate, which is one of the main wheat production governorates in Egypt, in order to introduce and encourage traditional wheat farmers to adopt raised-bed technology package so as to benefit from the associated positive impacts on land and water use efficiency, on wheat production and subsequently farmers' livelihoods. However, farmers' decision regarding the adoption of this new technology package is influenced by several factors. This study sought to identify such factors, which can be help us understand and explain the reasons behind farmers' positive or negative attitude towards adopting wheat cultivation on raised beds. The conclusions and recommendations resulting from the study will be useful to develop effective policy and institutional interventions that encourage farmers' adoption of this new technology, which will in turn contribute to achieving Egypt's goal of raising self-sufficiency in wheat.

Many studies have been carried out in different locations of the world to try to explain farmers' behavior towards their adoption or rejection of certain technologies, methodologies or approaches. Among these are Beteo Zongo et al (2015) in Burkina Faso, Keelan and Thorne (2009) in Ireland, Ahmed et al (2013) in Kenya, and Jin-na 
and Lu-tang (2012) in China. The underlying study is among the first studies aiming at assessing farmers' behavior in Egypt towards the adoption of MRB technology.

The remainder of the paper is organized as follows: Section 2 presents the study area and data collection procedure. The methodological framework, with special emphasis on the logistic regression model, is presented in the third section. Section 4 presents and discusses the empirical findings from this research study while section 5 concludes.

\section{Study Area and Data Collection}

\subsection{Study Area}

The study area is located in Sharkia Governorate (See Map), which is located in the Eastern Nile Delta Region. Sharkia is the third most populous of Egypt's 27 governorates. Out of an estimated 6,485,000 people (2015 estimate), 77\% live in rural areas. With an area of about $4,180 \mathrm{~km}^{2}$ covering most of the Eastern Nile Delta, population density is about $1,600 / \mathrm{km}^{2}$. Sharkia is one of the largest Egyptian governorates in terms of agricultural land area. Agricultural lands in the governorate are estimated at about 360 thousand ha, representing about $86 \%$ of the total area of the governorate.

During the agricultural cropping season 2013/2014, total wheat planted area at the level of Sharkia Governorate amounted to 188 thousand ha. Of this total, the area of wheat under raised-bed system reached approximately 29.74 thousand ha representing $15.81 \%$ of Sharkia's total wheat planted area. Raised-bed technology has been introduced to farmers in the selected governorate in collaboration with extension agents and other relevant institutions through organizing specialized training activities over various field days.

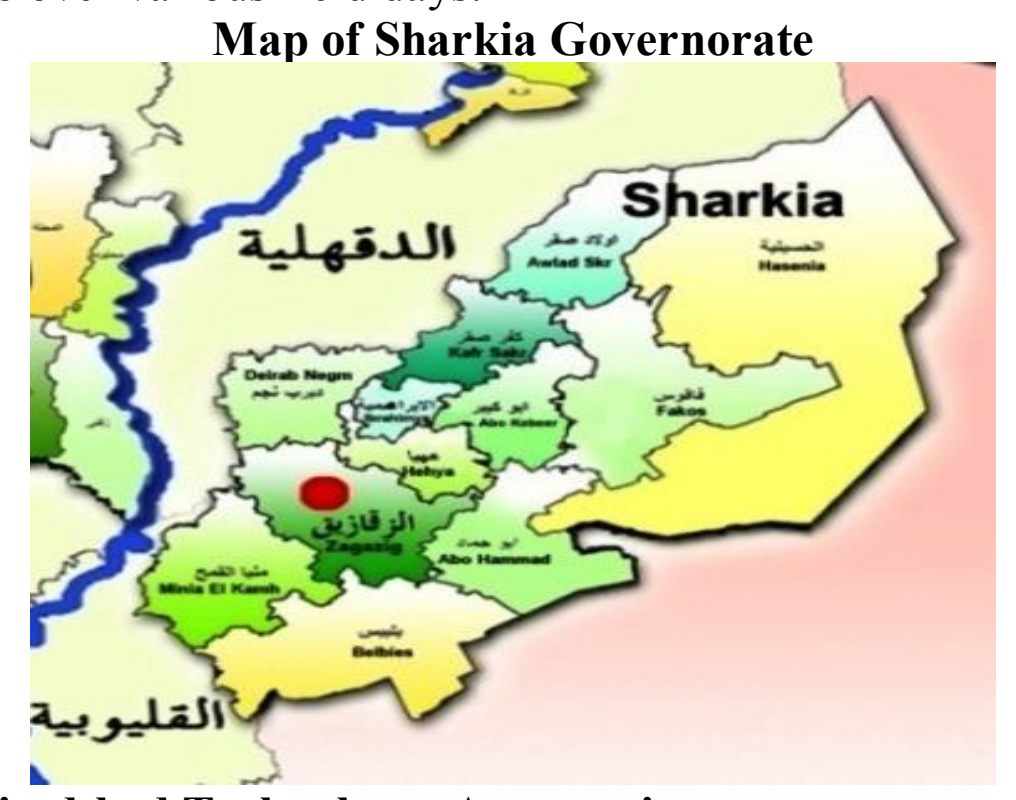

\subsection{Applied Raised-bed Technology: An overview}

Raised-bed technology is a farming system that makes use of natural resources more efficiently compared to the long applied flat traditional cultivation of wheat. As compared to the traditional system, raised-bed technology offers higher efficiency in terms of cultivable land use, as well as efficiency in the use of essential inputs such as irrigation water, seeds and fertilizers. Increases in these efficiencies result in reduced 
Econometric Analvsis of Factors Affecting Farmers' Adoption of Water । $\diamond \vee \leq$

Saving Technologies: A Case Study of Raised-bed Technology in Egypt

production cost, improved wheat yield, and subsequently increase in net return earned by farmers compared to that earned from wheat grown under the flat traditional system.

Raised bed technology requires using a tractor equipped with different tools used in soil leveling and building raised beds, in addition to using improved wheat seed varieties including Misr 1, Misr 2, Sakha 93, Sids 12, Giza 168, Shandaweel, Gammiza 11, and Gammiza 9. Extension officers also play an important role in this technology package, where they provide adopters with information on the proper timing for cultivation, the quantity of seeds per feddan, proper irrigation times and shifts, types of diseases that might infect wheat and proper treatment, proper types and quantities of fertilizers, and the proper time for crop harvesting.

\section{Methodological Framework}

\subsection{Source of Data}

Since household is the basic unit of analysis in many social, microeconomic, and governmental models, a representative sample of 70 rural households was randomly drawn from the study area in Sharkia Governorate in order to collect the primary data and information required to achieve the study objectives. Since the head of the household is usually assumed the decision maker in adoption studies, heads of the sample households were interviewed using a questionnaire that was designed to cover a range of socioeconomic questions, the answers of which serve to achieve the objectives of this study. Out of the 70 households, 35 represent households that adopted raised bed farming, i.e., fifty percent of the sample; whereas the other 35 represent households that still perform traditional wheat farming.

\subsection{Variable Selection and Hypotheses}

As illustrated in Table (1), the following dependent and explanatory variables and hypotheses have been used in the model:

\subsubsection{Dependent Variable}

When analyzing farmers' response to adopting new practices, methods, or technologies, adoption is usually defined in terms of a binary variable; i.e., adoption versus non-adoption. In this case study, ADOP (adoption), which is the dependent variable $\mathrm{Y}_{\mathrm{i}}$, is referred to as a binary variable that takes the value 1 for those farmers who adopted the raised bed technology package, whilst takes the value 0 for farmers who did not adopt it.

\subsubsection{Explanatory Variables and Hypotheses}

Adoption of raised bed farming is an attitude that is influenced by several interrelated factors. The study used 14 potential explanatory variables representing a variety of factors that are assumed to influence farmers' adoption of raised bed farming in the study area. Details regarding the 14 variables and hypothesized relationship according to the logic of economic theory are presented in what follows.

AGE is a categorical variable that refers to the age of household heads. It is hypothesized that younger household members are more likely to apply new methods, practices, and technologies than older farmers. It is therefore expected that age has a negative impact on farmer's adoption of raised bed farming. 
EDUC is a categorical variable that refers to the educational background of household heads. It is hypothesized that farmers with higher educational levels are more likely to adopt new methods, practices, or technologies than less educated ones. It is therefore expected that EDUC has a positive impact on farmer's adoption of raised bed.

FSIZ is a categorical variable that refers to the number of people per household. Since raised bed farming is a labor-intensive farming method, it is hypothesized that households with larger family size thus labor force are more likely to adopt new technologies than households with less family size. Therefore, it is expected that FSIZ has a positive impact on the adoption of raised bed farming in this study.

FEXP measures the farming experience of household heads in years. It is hypothesized that household heads with more farming experience are more likely to adopt new methods, practices, or technologies than those with less farming experience. It is therefore expected that FEXP has a positive relationship with the adoption of raised bed farming.

LABE refers to the number of work days spent by labor force. For this variable, it is hypothesized that the more the number of work days spent in planning and planting the more likely the household head will adopt this method. Therefore, a positive relationship is expected between LABE and farmer's adoption of raised bed farming.

TENUR refers to the status of land ownership. In the study sample, agricultural land holdings are either fully owned, or part is owned and the other is rented. It is well known that farmers who rent agricultural land are not likely to invest in adopting new technologies. However, the presence of such mixed type of tenure makes it difficult to predict the impact this variable has on farmer's adoption of raised bed farming. Therefore, the impact of TENUR on farmers' decision regarding adoption is unclear.

OFFA is the variable that refers to practicing off-farm activity. It is a dummy variable that takes the value 1 if the farmer has any off-farm activity, and 0 if not. Since the role off-farm activity plays in making the decision on whether or not to adopt raised bed farming method is unclear, it is not possible to predict the sign of this variable.

INCO is a categorical variable that refers to family income. Farmers in families with higher level of income are more likely to adopt new farming methods as they can afford to pay the required investment. Therefore, a positive relationship is expected between INCO and farmers' adoption of raised bed farming.

CRED is a dummy variable that refers to the famers' access to credit. It takes the value 1 if the farmer has obtained credit, and 0 if not. Farmers' access to credit is expected to help them raise the level of their crop production and thus their income and living standards. As such, CRED is expected to have a positive impact on farmers' adoption of raised bed farming.

CBOS refers to the membership of community-based organizations. It is a dummy variable that takes the value 1 if the farmer is a member, and 0 if not. Since community-based organizations are supposed to offer various useful services to member farmers to help them improve their production, CBOS is expected to have a positive impact on farmers' adoption of raised bed farming.

VLIVST refers to the importance livestock represents in the farming system. It is another dummy variable that takes the value 1 if livestock is important in the farming system, and 0 if not. In the study area, livestock has several advantages. It is 


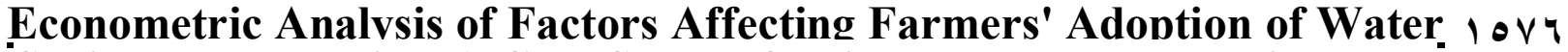

Saving Technologies: A Case Study of Raised-bed Technology in Egypt

used to perform some agricultural operations, provide manure to improve production and reduce fertilizer cost, and to provide the milk required for family consumption. Livestock is fed on wheat straw, which is the by-product of wheat crop. And since the sample consists of small farmers who own a few heads of livestock and grow wheat mainly for human consumption not to produce animal feed, the expected importance of livestock in the farming system in study area is unclear.

CONT refers to farmer's contact with research and extension officers. It is also a dummy variable that takes the value 1 if the farmer has contact with research and extension officers, and 0 if not. No doubt, contact with research and extension officers provides farmers with valuable information, updates on the new farming methods and technologies, and helps them solve the problems they encounter. Therefore, CONT is expected to have a positive relationship with the adoption of raised bed farming.

KNT represents the knowledge of raised bed farming. It is a dummy variable that takes the value 1 if the farmer has knowledge of the new farming method and technology, and 0 if not. It is hypothesized that farmers who have previous knowledge about the introduced new technology are more likely to adopt it than those who have never heard about it. Therefore, KNT is expected to have a positive impact on the adoption of raised bed farming.

ATTI refers to the farmer's attitude or perception towards the adoption of raised bed farming. It is a dummy variable that takes the value 1 if the farmer's attitude is positive, and 0 if negative. Since the purpose of introducing raised bed farming is to increase wheat production thus revenue earned by farmers and water use efficiency, then a positive attitude is expected to have a positive impact on the adoption of raised bed farming.

\subsubsection{The Empirical Model}

Since conventional regression analysis (Ordinary Least Squares or OLS) cannot accommodate zero observations on the dependent variable, Logistic Regression is used instead to predict a categorical (usually dichotomous) variable from a set of predictor variables. In this case study, the research is predicting an event that has two possible outcomes, adopt vs. not adopt, which means that the dependent variable is not continuous but has only two possible outcomes, 1 or 0 . This case infringes the assumption that the variable is normally distributed (single peak), since a 1/0 variable by definition has a binomial distribution (double peak). The Binary Logistic Model (Logistic Regression Model) solves this problem by putting the predicted dependent variable as a function of the probability that a particular subject will be in one of the categories, i.e., by determining the odds of 1 or 0 (Peng and So, 2002), if the odds of 1 are higher than those of 0 , then a 1 would be expected and not a 0.

This is accomplished by estimating the Log Odds Ratio, which is the log of the odds of 1 divided by the odds of 0 . Since odds are a probability, there will be a ratio of 2 positive numbers. The log of a positive number can have a value between infinity and + infinity, which removes the upper and lower bound on the dependent variable, which can now be estimated by a regular regression model (using OLS estimation procedure). The Binary Logistic Regression was applied in this research to regress the dependent variable, Y, of whether the household's head has adopted raised bed farming,

$\mathrm{Y}=\left\{\begin{array}{l}1 \text { : adopted } \\ 0: \text { Otherwise }\end{array}\right.$ 
against the factors affecting household head's adoption decision.

Let $X_{i}$ represent the set of factors influencing the adoption decisions of the $i^{\text {th }}$ farmer. For the farmer, $Y_{i}$ is an indirect utility derived from the adoption decision, which is a linear function of $\mathrm{k}$ explanatory variables $(\mathrm{X})$, and is expressed by the following prediction equation:

$$
\begin{aligned}
\mathrm{Y}_{\mathrm{i}} & =\ln \{\operatorname{odds}(\text { event })\} \\
& =\ln \{(\text { prob(event }) / \operatorname{prob}(\text { nonevent })\} \\
& =\ln \{(\text { prob(event }) / 1-\operatorname{prob}(\text { event })\} \\
& =\ln \left(\frac{\mathrm{Y}}{1-\widehat{\mathrm{Y}}}\right)=\alpha+\sum_{i=\mathbf{1}}^{n} \beta_{\mathrm{i}} \mathrm{X}_{\mathrm{kt}} \\
& =\alpha+\beta_{1} \mathrm{X}_{1}+\beta_{1} \mathrm{X}_{1}+\beta_{2} \mathrm{X}_{2}+\ldots \ldots . .+\beta_{\mathrm{k}} \mathrm{X}_{\mathrm{k}}
\end{aligned}
$$

Where $\widehat{Y}$ is the predicted probability of the event coded with 1 (adopt), $(1-\widehat{Y})$ is the predicted probability of the other decision, $\alpha$ is the intercept, and $X_{\mathrm{k}}$ represents the following predictor variables: AGE, EDUC, FSIZ, FEXP, LABE, TENUR, OFFA, INCO, CRED, CBOS, VLIVST, CONT, KNT, and ATTI, whereas $\beta_{1}, \beta_{2}, \beta_{3}, \ldots, \beta_{\mathrm{i}}$ are the coefficients associated with each explanatory variable $X_{1}$ to $X_{k i}$. The model can therefore be expressed as follows:

$$
\begin{aligned}
& \text { Y }=\alpha+\beta_{1 \mathrm{AGE}}+\boldsymbol{\beta}_{2 \mathrm{EDU}}+\boldsymbol{\beta}_{3 \mathrm{FSIZ}}+\boldsymbol{\beta}_{4 \mathrm{FEXP}}+\boldsymbol{\beta}_{5 \mathrm{LABE}}+\boldsymbol{\beta}_{6 \mathrm{TENUR}}+\boldsymbol{\beta}_{7 \mathrm{OFFA}}+\boldsymbol{\beta}_{\mathbf{8 I N C O}}+\boldsymbol{\beta}_{9 \mathrm{CRED}}+ \\
& \boldsymbol{\beta}_{10 \mathrm{CBOS}}+\boldsymbol{\beta}_{11 \mathrm{VLIVST}}+\boldsymbol{\beta}_{12 \mathrm{CONT}}+\boldsymbol{\beta}_{13 \mathrm{KNT}}+\boldsymbol{\beta}_{14 \mathrm{ATTI}}+\boldsymbol{\xi} \text { Eq. (2) } \\
& \text { The fourteen potential explanatory variables (Table 1) expected to influence the } \\
& \text { adoption decision of MRB in study areas include a wide variety of socio-economic, } \\
& \text { farming and institutional factors. }
\end{aligned}
$$

\section{Results and Discussion}

\subsection{Model Estimation Procedure and Validity}

The binary logistic regression model has been estimated using SPSS 20.0. The model is constructed by an iterative Maximum Likelihood Estimation (MLE) procedure in which the program starts with arbitrary values of the regression coefficients to construct an initial model for predicting the observed data. It will then evaluate errors in the prediction and changes the regression coefficients in order to make the likelihood of the observed data greater under the new model. The procedure is repeated until the model converges, i.e., until the differences between the newest model and the previous model are trivial. Descriptive statistics of variables used in the empirical econometric model and results of the model estimated using binary logistic regression are presented in Tables (2) and (3).

To assess the validity of the estimated model, the Hosmer and Lemeshow Goodness-of-Fit Test, which is one of the most reliable tests of model fit for binary regression, has been used. Test results showed that overall, the predictions were correct 54 out of 70 times, for an overall success rate of $77.1 \%$, i.e., the percentage of correct predictions is $77.1 \%$. 
Econometric Analvsis of Factors Affecting Farmers' Adoption of Water, lov $\mathrm{A}$ Saving Technologies: A Case Study of Raised-bed Technology in Egypt

Table (1): Description of the Variables Entered in the Empirical

Binary Logistic Model

\begin{tabular}{|c|c|c|c|}
\hline Acronym & Description & Type of Measure & $\begin{array}{l}\text { Expected } \\
\text { Sign }\end{array}$ \\
\hline $\begin{array}{c}\text { Dependent } \\
\text { Variable } \\
\text { ADOP }\end{array}$ & Whether a farmer has adopted or not & Dummy ( 1 if yes, 0 if not) & \\
\hline \multicolumn{4}{|l|}{$\begin{array}{l}\text { Explanatory } \\
\text { Variables }\end{array}$} \\
\hline AGE & Household Head's Age & $1,2,3,4$ & - \\
\hline EDU & $\begin{array}{l}\text { Household Head's Educational } \\
\text { background }\end{array}$ & $1,2,3,4,5$ & + \\
\hline FSIZ & Household in number of people & $1,2,3,4,5,6$ & + \\
\hline FEXP & Household head's farming experience & Years & + \\
\hline LABE & Labor Force Size & $\begin{array}{c}\text { Active labor force in } \\
\text { numbers }\end{array}$ & + \\
\hline TENUR & Status of Land Ownership & $\begin{array}{l}\text { 1, fully owned; } 2 \text {, mixed } \\
\text { (owned }+ \text { rented land) }\end{array}$ & $?$ \\
\hline OFFA & Off-Farm Activity & Dummy ( 1 if yes, 0 if not) & $?$ \\
\hline INCO & Level of Family Income & $1,2,3,4,5$ & + \\
\hline CRED & Accessed Credit & Dummy ( 1 if yes, 0 if not) & + \\
\hline CBOS & $\begin{array}{c}\text { Member of Community Based } \\
\text { Organizations }\end{array}$ & Dummy ( 1 if yes, 0 if not) & + \\
\hline VLIVST & $\begin{array}{c}\text { Importance of Livestock In The } \\
\text { Farming System }\end{array}$ & Dummy ( 1 if yes, 0 if not) & $?$ \\
\hline CONT & Contact with Research and Extension & Dummy ( 1 if yes, 0 if not) & + \\
\hline KNT & Knowledge of the New Technology & Dummy ( 1 if yes, 0 if not) & + \\
\hline ATTI & $\begin{array}{l}\text { Farmer's Attitude Towards Raised bed } \\
\text { Farming }\end{array}$ & $\begin{array}{l}\text { Dummy ( } 1 \text { feels it will have } \\
\text { positive effect, } 0 \text { if negative) }\end{array}$ & + \\
\hline
\end{tabular}

\section{Source: Own elaboration (2015)}

The test yielded a Chi-square of 6.615, with a p-value (significance) of 0.579, indicating a good fit for the estimated binary logistic regression model. Based on the test results, the null hypothesis that there is no difference between the observed and predicted values of the dependent variable is accepted, which means that the model estimates fit very well with the used data set at an acceptable level.

Table (2): Descriptive Statistics of Variables used in the Empirical

Econometric Model

\begin{tabular}{|c|c|c|c|c|c|}
\hline Variable & $\mathbf{N}$ & Minimum & Maximum & Mean & Std. Deviation \\
\hline ADOP & 70 & 0 & 1 & 0.5 & 0.504 \\
\hline AGE & 70 & 2 & 4 & 3.5 & 0.654 \\
\hline EDUC & 70 & 1 & 5 & 3.03 & 1.362 \\
\hline FSIZ & 70 & 1 & 6 & 2.06 & 0.679 \\
\hline FEXP & 70 & 6 & 60 & 33.79 & 12.947 \\
\hline LABE & 70 & 28 & 121 & 69.4 & 24.69 \\
\hline TENUR & 70 & 1 & 2 & 1.24 & 0.432 \\
\hline OFFA & 70 & 0 & 1 & 0.8 & 0.403 \\
\hline INCO & 70 & 1 & 5 & 1.29 & 0.725 \\
\hline CRED & 70 & 0 & 1 & 0.27 & 0.448 \\
\hline CBOS & 70 & 0 & 1 & 0.7 & 0.462 \\
\hline VLIVST & 70 & 0 & 1 & 0.57 & 0.498 \\
\hline CONT & 70 & 0 & 1 & 0.91 & 0.282 \\
\hline KNT & 70 & 0 & 1 & 0.53 & 0.503 \\
\hline ATTI & 70 & 0 & 1 & 0.36 & 0.483 \\
\hline Valid N & 70 & & & & \\
\hline Soe:
\end{tabular}

Source: Own elaboration from survey data set (2015). 
المجلة المصرية للاقتصاد الزراعي - المجلا الثامن والعشرون - العدد الثالث - سبتمبر 1 1 ـ

Table (3): Parameter Estimates of the Binary Logistic Regression Model for Factors Affecting Wheat Farmers' Adoption of Raised-Bed Farming System in Sharkia Governorate in Egypt

\begin{tabular}{|c|c|c|c|c|c|c|}
\hline Variable & B & S.E. & Wald & df & Sig. & Exp(B) \\
\hline Age & -1.621 & 0.731 & 4.922 & 1 & 0.027 & 0.198 \\
\hline Educ & 0.510 & 0.345 & 2.184 & 1 & 0.139 & 1.665 \\
\hline Fsiz & 1.111 & 0.778 & 2.040 & 1 & 0.153 & 3.038 \\
\hline Fexp & 0.074 & 0.036 & 4.279 & 1 & 0.039 & 1.077 \\
\hline Labe & -0.021 & 0.017 & 1.684 & 1 & 0.194 & 0.979 \\
\hline Tenur & 1.424 & 0.944 & 2.276 & 1 & 0.131 & 4.154 \\
\hline Offa & -1.217 & 0.964 & 1.596 & 1 & 0.207 & 0.296 \\
\hline Inco & 0.587 & 0.635 & 0.856 & 1 & 0.355 & 1.799 \\
\hline Cred & 0.242 & 0.760 & 0.101 & 1 & 0.750 & 1.274 \\
\hline Vlivst & 0.389 & 0.861 & 0.204 & 1 & 0.652 & 1.475 \\
\hline Cont & -0.221 & 0.755 & 0.086 & 1 & 0.769 & 0.801 \\
\hline Knt & 0.142 & 1.455 & 0.010 & 1 & 0.922 & 1.152 \\
\hline Atti & 2.369 & 0.781 & 9.213 & 1 & 0.002 & 10.692 \\
\hline Constant & -2.998 & 0.860 & 1.345 & 1 & 0.246 & 2.712 \\
\hline
\end{tabular}

Note: Hosmer and Lemeshow Test: Chi-square:6.615; d.f.: 8; Sig.: 0.579.

-2log likelihood: 67.221; Cox\&Snell $R^{2}: 0.347$; Nagelkerke $R^{2}: 0.463$; overall percentage of right predictions: $77.1 \%$. No variables have been omitted.

Source: Own elaboration from survey data set (2015).

Regarding $\operatorname{Exp}(\mathrm{B})$, the exponentiation of the $\beta$ coefficient, it is an odds ratio. This value is given by default because the odds ratios are easier to interpret than the coefficient, which is in log-odds units. It indicates the predicted change in the odds associated with a unit increase in one explanatory variable, holding all other explanatory variables constant.

In regards to the significance of the explanatory variables in the model, it is clear from the table that six of them range between highly to fairly significant in explaining wheat farmer's response to the adoption of raised bed farming in Sharkia Governorate of Egypt; these are KNT (at 1\% level of significance); AGE and FEXP (at 5\% level of significance); and EDUC, FSIZ and TENUR (at 15\% level of significance). As for the rest of variables, including LABE, OFFA, INCO, CRED, CBOS, VLIVST, CONT and ATTI, they proved insignificant as predictors of raisedbed farming adoption. The following is the estimated logistic regression equation:

$$
\begin{aligned}
\mathrm{Y} & =-2.601-(1.621 * \mathrm{AGE})+(0.510 * \mathrm{EDU})+(1.111 * \mathrm{FSIZ})+(0.074 * \mathrm{FEXP})-(0.021 * \mathrm{LABE}) \\
& +(1.424 * \text { TENUR })-(1.217 * \text { OFFA })+(0.587 * \text { INCO })+(0.242 * \mathrm{CRED})+(0.389 * \mathrm{CBOS}) \\
& -(0.221 * \mathrm{VLIVST})+(0.142 * \mathrm{CONT})+(2.369 * \mathrm{KNT})+(0.998 * \mathrm{ATTI})
\end{aligned}
$$

These estimates explain the relationship between the dependent variable and the explanatory variables, where the dependent variable is on the logit scale. They show the amount of change (increase/decrease) in the predicted log odds of $\mathrm{ADOP}=1$ that would be predicted by a unit increase in the predictor, holding all other predictors constant, which will be discussed in the following section.

\subsection{Empirical Findings of the Model and Discussion}

As hypothesized, analysis results showed that KNT has a significant positive relationship with farmers' adoption decision at $1 \%$ level of significance, which means 
Econometric Analvsis of Factors Affecting Farmers' Adoption of Water. $10 \wedge$.

Saving Technologies: A Case Study of Raised-bed Technology in Egypt

that this variable is highly significant in explaining farmer's decision regarding the adoption of raised-bed technology. Such result indicates that farmers who have previous knowledge about the new farming technology are more likely to adopt it than those with no knowledge about it. $\operatorname{Exp}(\mathrm{B})$, which gives the predicted change in the odds/probabilities associated with a unit increase in the corresponding explanatory variable, indicates that, holding all other explanatory variables constant, for every unit increase in KNT, the probability of adopting raised-bed farming is expected to increase by 10.692 times.

Results also indicate that, at 5\% level of significance, two variables proved to have significant impact on farmer's adoption decision, AGE and FEXP. AGE showed a negative relationship with farmer's adoption decision, which means that the probability of adopting raised bed technology is higher among younger farmers than older ones; whereas FEXP has a positive relationship with farmer's adoption decision, indicating that farmers with longer farming experience are more likely to adopt raised-bed technology than those with less farming experience. $\operatorname{Exp}(B)$ indicates that, for every unit increase in AGE the probability of adoption is expected to decline by 0.198 times; while for every unit increase in FEXP the probability of adoption is expected to increase by 1.077 times. It is worth noting that the high value of standard deviation for this variable can be attributed to the large variations in sample farmers' ages thus the number of years spent in the field.

Analysis results also revealed that EDUC, FSIZ and TENUR proved to have positive relationships with farmer's adoption decision as hypothesized. And although the level of significance exceeds $10 \%$ for the three variables, where it reached $15 \%$, it can be accepted in such kind of analysis that uses categorical variables.

For EDUC, this result indicates that farmers with higher educational background are more likely to adopt raised-bed technology than less educated ones. $\operatorname{Exp}(B)$ indicates that, holding all other explanatory variables constant, for every unit increase in EDUC the probability of adopting raised bed farming is expected to increase by 1.665 times.

As for FSIZ, results indicate that farmers who have bigger family sizes are more likely to adopt raised-bed technology. $\operatorname{Exp}(\mathrm{B})$ indicates that, holding all other explanatory variables constant, for every unit increase in FSIZ the probability of adopting raised bed technology is expected to increase by 3.038 times. Coming to TENUR, for which the hypothesis regarding the expected impact on adoption is unknown, results indicate that farmers who own land are more likely to adopt raised bed technology than those who rent it. $\operatorname{Exp}(B)$ indicates that, holding all other explanatory variables constant, for every unit increase in land ownership, the probability of adopting raised bed farming is expected to increase by 4.154 times.

In regards to the rest of the explanatory variables, results indicate that LABE, OFFA, INCO, CRED, CBOS, VLIVST, CONT and ATTI are not significant as predictors of raised-bed technology adoption. However, their signs can still be interpreted.

For LABE variable, contrary to what has been hypothesized, analysis showed a negative relationship with farmer's adoption of raised-bed technology. The sign 
implies that LABE is not a determinant variable for adopting raised-bed system, which might be attributed to farmers' preference to benefit from the already available family labor force than to use mechanical work in order to save money; and to owning small farm holdings for which machinery is not that much required. It is worth mentioning that the high value of standard deviation associated with this variable can be attributed to the large variations in the number of work days spent in field work depending on whether or not the farmer uses MRB machine.

As for OFFA variable, for which the expected impact on adoption has been hypothesized as unclear, analysis results returned a negative relationship with farmer's adoption decision. However, the sign implies that households with more members engaged in off-farm activities are less likely to adopt raised bed technology.

As expected, INCO showed a positive relationship with MRB adoption decision, implying that households with higher income are more likely to adopt raised bed technology.

CRED also showed a positive relationship with MRB adoption decision as hypothesized, implying that households that have access to credit are more likely to adopt raised bed technology.

The positive sign accompanying CBOS implies a positive relationship with MRB adoption decision as hypothesized, which means that farmers who are members of community-based organizations are more likely to adopt raised bed technology.

As for VLIVST, for which the expected impact in the farming system in the study area was hypothesized as unclear, results returned a negative sign, indicating a negative relationship between the importance livestock represents in the farming system and MRB adoption decision, which means that the less important livestock is to the farmer, the more likely he adopts MRB.

CONT, which refers to farmer's contact with research and extension officers, showed a positive relationship with MRB adoption decision as hypothesized, implying that farmers who have contact with research and extension officers are more likely to adopt raised bed technology.

Finally, ATTI showed a positive relationship with MRB adoption decision as hypothesized, implying a positive attitude or perception towards MRB adoption.

\subsection{MRB Technology Adoption: A Synthesis}

Adoption of MRB technology is influenced by several determinants such as farmers' resource endowment and socioeconomic characteristics, in addition to institutional and policy factors. In terms of resource endowment, farmers in the study area have small size holdings, limited freshwater due to falling at the tail of irrigation canals and abundant family labor force. As for the socioeconomic characteristics, significant explanatory variables that influence farmers' adoption of raised-bed technology include: Knowledge of the New Technology (KNT); household head's age (AGE); farming experience (FEXP); household head's educational background (EDUC); number of people living in the household (FSIZ); access to credit (CRED), and finally the Status of Land Ownership (TENUR).

Turning to institutional and policy factors influencing farmers' adoption of MRB technology, the main determinants of MRB technology adoption include extension agencies, cooperatives and relevant research centers, namely the Agricultural Research Center (ARC) and affiliated agricultural mechanization 
Econometric Analvsis of Factors Affecting Farmers' Adoption of Water । $\diamond \wedge$ r

Saving Technologies: A Case Study of Raised-bed Technology in Egypt

stations. ARC is responsible for studying and solving the technical problems associated with MRB machine, in addition to developing the currently available machine so that it can be used for planting other crops, not only wheat. However, dissemination of knowledge \& information to all farmers and making the newly developed machinery available at reasonable cost or rent for farmers with limited financial resources represent a problem due to the weak role of extension agencies and cooperatives.

\section{Concluding remarks and Policy Implications}

Based on the achieved results, promoting the adoption of wheat cultivation on raised beds requires formulating a set of policies and alternative instruments that aim to activate the role of agricultural extension in providing farmers with information and updates on appropriate new farming systems and technology packages in order to increase their knowledge about the introduced technology package and associated benefits as KNT variable (knowledge of the New Technology) proved to play a very significant role in influencing farmers' adoption decision. In addition, there is a need to formulate a set of policies and alternative instruments targeting young farmers with the aim of improving their level of education, where both age and education proved to have significant impact on farmers' attitude towards adoption.

Since farming experience also proved to have significant impact on farmers' adoption decision, there is a need to design and develop policies and alternative instruments and institutions for activating the role of agricultural extension, cooperatives and the private sector in providing technical assistance services and organizing training programs to transfer the know-how to wheat farmers through practical training in order to help them build experience and improve their skills, which is bound to facilitate adoption of the introduced technology package.

There is also a need for activating the role of agricultural cooperative societies in providing the machinery required for implementing raised-bed technology package to tenant farmers at a reasonable cost, which will encourage them to adopt the introduced new technology package. Moreover, farmers' access to credit should also be enhanced to allow them access to the machinery as well as essential inputs to increase their overall productivity.

\section{Acknowledgment}

This study was undertaken as part of the Water and Livelihoods Initiative (WLI)'s work in Egypt which was implemented by the Agricultural Research Center (ARC) in collaboration with the International Center for Agricultural Research in the Dry Areas (ICARDA). Funding for the project was provided by the United States Agency 439 for International Development (USAID).

\section{References}

1. Abd El-Hafez S.A.; "Fact Checking Assessment of Raised Bed Machine", Report prepared for ICARDA, 2015.

2. Ahmed, K.H., Chalmers, K. and Khlif, H. "A meta-analysis of IFRS adoption effects", The International Journal of Accounting, Vol. 48 No. 2, pp. 173-217, 2013

3. Amemiya, T.; Advanced Econometrics, Harvard Univ. Press, 1985. 
4. Beecher, G., Thompson, J.A., Dunn, B.W. and Mathews, S.K.; "Permanent Raised Beds in Irrigated Farming Systems in the Murrumbidgee/Murray Valleys of NSW". Proceedings of a workshop held in Griffith, Australia, 1-3 March 2005. ACIAR Proceedings No. 121, 2005.

5. Berihun Kassa Hailu \& Others;"Adoption And Impact Of Agricultural Technologies On Farm Income: Evidence From Southern Tigray, Northern Ethiopia". International Journal of Food and Agricultural Economics, Vol. 2 No. 4, pp. 91-106, 2014.

6. Beteo Zongo \& Others;"Farmers' Practices and Willingness To Adopt Supplemental Irrigation In Burkina Faso". International Journal of Food and Agricultural Economics, Vol. 3 No. 1: pp. 101-117, 2015

7. Chao-Ying Joanne Peng and Tak-Shing Harry So;"Logistic Regression Analysis and Reporting: A Primer". Department of Counseling and Educational Psychology, Indiana University-Bloomington. Understanding Statistics, I(1), pp. 31-70.

8. Conor Keelan and Fiona S. Thorne;"Predicted Willingness of Irish Farmers to Adopt GM Technology". AgBioForum, Vol. 12 No. (3\&4): pp. 394-403, 2009.

9. Ibrahim Ahmed and Others;"Evaluation of Types and Factors Influencing Adoption of Rainwater Harvesting Techniques in Yatta District, Kenya". International Journal of Education and Research, Vol. 1 No. 6 June, 2013.

10.Jing-na Tian and Lu-tang Li; Factors Influencing Willingness and Ability of Farmers to Adopt New Technologies: A Case Study of Guanzhong Area, Asian Agricultural Research, vol. 04, issue 07, 2012.

11.Roth, C.H., Fischer, R.A. and Meisner, C.A. ed.; "Evaluation and Performance of Permanent Raised Bed Cropping Systems in Asia, Australia and Mexico". Proceedings of a workshop held in Griffith, Australia, 1-3 March 2005. ACIAR Proceedings No. 121, 2005

12.Tanya J. Hal;"Factors Affecting Growers' Willingness to Adopt Sustainable Floriculture Practices". HORTSCIENCE, Vol. 44(5):pp 1346-1351, 2009.

13.TIAN Jin-na \& Li Lu-tang;"Factors Influencing Willingness and Ability of Farmers to Adopt New Technologies: A Case Study of Guanzhong Area, China". Asian Agricultural Research, Vol. 4 No. 7: pp. 37-40, 44, 2012.

14.Tisdall J.M. and Adem H.H.; "An Example of Custom Prescribed Tillage in South Eastern Australia. Journal of Agricultural Engineering Research, 40, 23-32, 1988.

15.Xue-Feng He and Others;"Econometric Analysis of the Determinants of Adoption of Rainwater Harvesting And Supplementary Irrigation Technology (RHSIT) in the Semiarid Loess Plateau of China". Agricultural Water Management Journal, Vol. 8 9, pp 243-250, February 2007. 


\section{تحليل قياسي للعوامل المؤثرة على تبني المزارعين لتقتيات الزراعة الموفرة للمياه: دراسة} حالة لزراعة القمح على مصاطب في مصر

الملخص و التوصيات

تتاول البحث مشكلة نقص كفاءة استخدام الموارد الزر اعية في إنتاج القمح في مصر ، و على رأسها

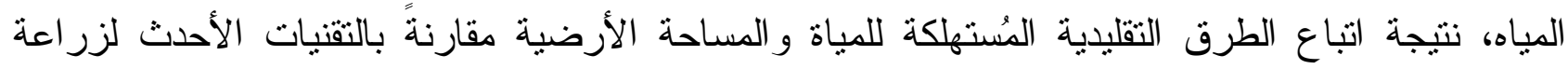
القمح مثل تقنية الزر اعة على مصاطب، و التي تم نشرها بين مز ارعي القمح التقليديين في محافظة الثرقية من خلال مشروع تابع لمبادرة المياه وسبل المعيشة (WLI) بغرض تحفيز هم على تبنيها للانتفاع من الأثنار الإيحابية لها على كفاءة استخدام الموارد في إنتاج القمح (الأرض و المياه ومدخلات الإنتاج الأخرى)، بالإضافة إلى تحسين انتاجية القمح بما يساهم في رفع معدل الاكتفاء الذاتي منه، وكذللك زيادة دخل المزارة وتحسين مستوى معيشته. وقد استهدف البحث التعرف على العوامل المؤثرة على تبني مزارعي القمح في

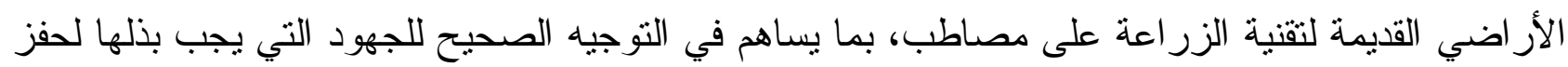

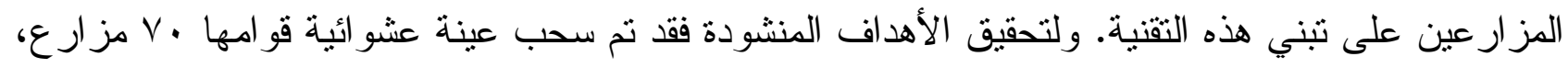

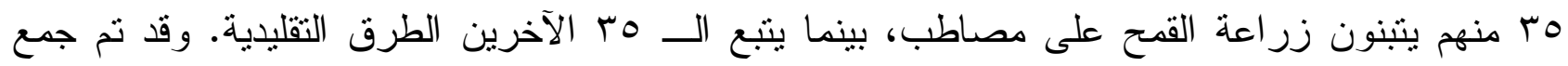
البيانات الأولية المطلوبة باستخدام استمارة استبيان تم تصميمها لخدمة أغر اض البحث. وللتوصل إلى لى العو امل المؤثرة على تبني المز ارعين لزر اعة القمح على مصاطب فقد تم تطبيق نموذج الانحدار اللوجستي باني الثنائي لقياس العلاقة بين المتغير التابع (ADOP) و عدد ؛ أ متغير مستقل محتمل تأثنر هم على تبني المزر اع للحزمة الجديدة في منطقة الدراسة. وقد أوضحت النتائج أن ج من المتغيرات المستقلة لها تأثنير

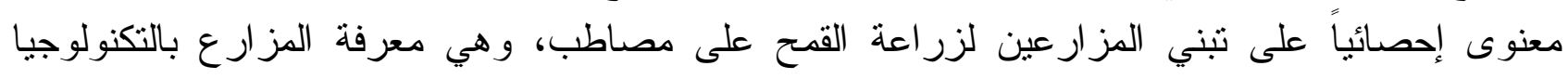
الجديدة (KNT)، العدر (AGE)، خبرة المزارع (FEXP)، مستوى التعليم (EDUC)، حجم الأسرة (FSIZ)، نوع الحيازة (TENUR). وقد ثبين أنه، بفرض ثبات جميع المتغير ات الأخرى فإن زيادة مقدار ها

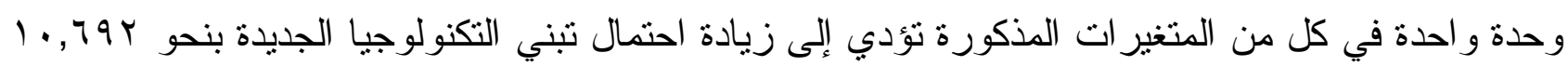

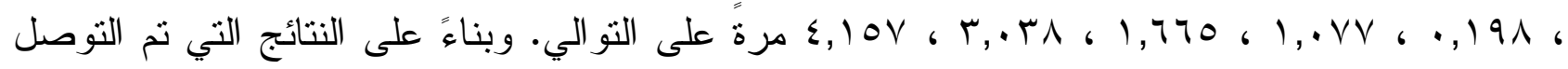
إليها فقد أوصى البحث بضرورة صياغة سياسات تستهدف تحسين مستوى تعليم شباب المزر اعون، وتتشيط دور الإزشاد الزر اعي وتحسين مستو اه لتقديم خدمات تساهم في بناء وتحسين خبرة المز ارعين، وتتشيط دور الجمعيات التعاونية الزراعية في توفير الألات الزر اعية المطلوبة لتطبيق هذه الحزمة التكنولوجية بتكلفة مخفضة لمستأجري الأر اضي الزر اعية، وكذلك تتشيط دور المر اكز البحثية، وبشكل خاص مركز البحوث الزر اعية ومحطات الميكنة التابعة له باعتباره المسؤول عن دراسة وحل المشاكل الفنية الخاصة بالماكينة المستخدمة في عمل المصاطب و العمل على تطوير ها بحيث يمكن استخدامها في زر اعة محاصيل أخرى بخلاف القمح. و أخير اَ، يجب السعي نحو نشر ونطبيق نفس المشروع التابع لــ (WLI) في الأر اضي القديمة الأخرى التي تتنشر بها زر اعة القمح. 